\title{
An Examination on Challenges and Prospectus of Radio 7
}

\author{
Amit Verma, Rayaz Hassan
}

\begin{abstract}
In real, it is not just good enough to obtain license, establish and start functioning radio station dedicated to society that called community radio station. The success of any body is hinged on the fulfillment of the objectives of that body. It is based on this premise that this research work is to find out and examine the present operational nature of campus Community Radio Station Radio 7 supported by The IIS University, Jaipur as a case study taken in comparison with the Objectives of its establishment, researcher also trying to find out the challenges and prospectus of the radio station in the process with the hope that it will be useful to the university management council on different issues regarding the operation, policy's, financial sustainability and equipping of the radio station.
\end{abstract}

Keywords : Community radio, challenges and visions of $C R$, Social development.

\section{INTRODUCTION}

Definition given by UNESCO "A Community radio is one that is operated in the community, for the community, about the community and by the community". Mass Media is actively working as a development tool in developing and under developed countries till date. But here, the question rises which media is devoted for peoples media. In relation to $\mathrm{CR}$, the term community refers to a pool or a group of people sharing common characters and interests. The term community can either be defined as a geographically-based set of persons or as social groups of the people who have common or detailed benefits. The idiom "a radio service by the people, close to the people and for the people" sums up the important features of this service. This means that CR must not only be run by but also serve the welfares of the society.

\section{History of Community Radio in India}

The advent of community radio in India was assured with a landmark judgment of Supreme Court delivered by Justice P.B. Sawant and Justice S. Mohan on February 9, 1995 in the case between the Union of India \& Cricket Association of Bengal. The court held that the airwaves or frequencies are a public property and have to be controlled and regulated by public authority in the interest of the public. The 'public property theory' could make the task of democratization of community radio very easy, coming as it does from the highest court in the country. (Saxena 2011, p.274)

Revised Manuscript Received on October 15, 2019.

* Correspondence Author

Amit Verma, Research Scholar, Department of Journalism \& Mass Communication, Manipal University, Jaipur, India.

Dr. Rayaz Hassan, Associate Professor \& HOD, Department of Journalism \& Mass Communication, Manipal University, Jaipur, India.
In December 2002, the Government of India approved a policy for the grant of licenses for setting up of CRS to well established educational institutions as well as IITs/IIMs. Again in November 2006, the case has been reevaluated by Government has now decided to broad base the policy by carrying 'Non-profit' organizations like civil society groups, State Agricultural Universities, Indian Council of Agricultural Research (ICAR) institutions, Krishi Vigyan Kendras (KVK), registered societies and public trusts. Now NGOs are permitted only to establish a CRS to serve the community within a range of $10-15 \mathrm{~km}$, but persons, political parties and other organization who want to make profit are not allowed to set up a CRS. This remarkable order to permit superior participation by the NGOs on issues relating to overall development \& social change.

\section{OBJCETIVES OF THE STUDY}

1. To find out the challenges affecting the effectiveness of the FM Radio 7.

2. To evaluate the operational structure of the FM Radio 7. 3. To analyze existing gaps between the aims of establishing the FM Radio 7 and its current operational function.

\section{Research Questions}

1. What are the aspects that influenced masses for establishment of FM Radio 7 by The IIS University?

2. What is the operational and administration structure of the FM Radio 7?

3. What is the financial sustainability of the FM Radio 7 ?

4. What is the formal relation of the operational function of FM Radio 7 in terms to the aims of establishing it?

\section{Profile of FM Radio 7}

Jaipur is the capital and the biggest city of the Indian state of Rajasthan. According to 2011 census, the city had a population of 3.1 million, creating it the tenth most populous city in the nation. Jaipur is also well-known as the Pink City, due to the dominant color scheme of its shops and buildings. A moment ago on 6 July 2019, UNESCO World Heritage Committee inscribed Jaipur the 'Pink City of India' among its World Heritage Sites. FM Radio 7 was launched on 7th March 2005 with a tagline of "Sada aapke sath" in the campus of The Indian International Institute of Management (IIIM) in Mansarovar in the locality of Jaipur on frequency 90.4 MHz It is the Second Educational community radio in Rajasthan and first community radio station run by private institute in India. Its broadcast programmes for eleven and half hours daily, from 6:30 am to $6 \mathrm{pm}$.

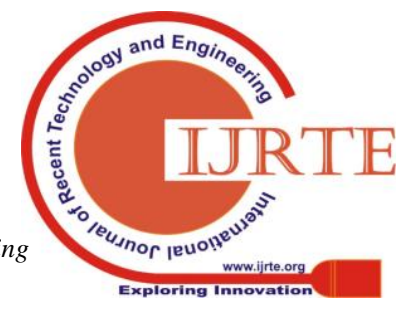


The station is supported by The IIS University's with own resources. Several Governmental and non-governmental agencies like UNICEF and many more are involved from time to time for content collaboration. In every morning station is broadcasting spirituality and devotional based programmes in the community for positive change. It also helps communities from programming in areas like education, health, culture, languages, environment and local issues. It also promotes Marwari language, art and culture and tradition of Rajasthan and India. It creates awareness in community regarding local governance and policies so as far as good many female students are actively participating in programming. Station revives and enriches folk music, dance and other infotainment activities among the listeners.

\section{REVIEW OF LITERATURE}

Sudarshan Sahoo \& Sunil Kant Behera (2017) found that community radio stations in Odhisha state, still a few in numbers, tried to bridge the communication gap created due to drastic disparities and distracted mainstream media. The paper focused on community radio station policies and public participation from local peoples. If new community radio stations can come up in the less developed regions of the state, they can play very significant role in bridging the gap between the government and the citizens.

Rachna Saini (2013) stipulates that CR movement appeared in India with the first community radio set up at Annamalai University. However it is a well-established part of development communication strategy across world to voice the concerns of the marginalized, specifically in under developed and developing societies, it is quite recent in India that the agenda of CR is being followed strongly especially after the Supreme Court milestone judgment about declaring the airwaves as public property.

Vinod Pavarala \& Kanchan K. Malik (2007) discuss about the initial struggle which was over with the Supreme Court decision in 1995 to declare airwaves public property. They talk about the process of de-monopolization of airwaves. The campaign for CR in India and guidelines began in 2006. The authors describe the civil society initiatives in rural India, including Namma Dhwani in 2001 at Boodikote village in the Kolar district of Karnataka, Ujjas radio at Kutch, Gujrat and Henval Vaani and Mandakini ki Awaaz established in the state of Uttarakhand. The authors discuss de-monopolization of air waves but do not talk about the very important issue of sustainability of community-run radio stations.

\section{RESEARCH METHODOLOGY}

According to objectives of this study, researcher adopted quantitative research method; and survey was selected as the research method for collecting important info for this study as it was considered the most suitable technique that can be used for the target population in view of the research topic. In this regard, the population or universe of this study is FM Radio 7 90.4 MHZ (The IIS University, campus radio). For the purpose of this study probability sampling was decided for a given population, each element of the population has a chance of being picked to be a part of the sample. Therefore,

for the purpose of this work, 170 (one hundred seventy) respondents from The IIS University, Jaipur were drawn randomly from among the campus authority, the station manager and students accessing the studio for practical training and listeners of the station to answer questions that was put to them in order to answer the research questions. Thus, one hundred seventy (170) questionnaires were distributed.

The questionnaire was designed keeping in mind research questions and objectives of the study in such a way that the variables were clearly identified as such getting the appropriate response necessary for significant clarifications becomes less strenuous. The questionnaire was created in the close-ended format and written in bilingual language to aid general understanding and provoke accurate responses from the respondents.

\section{DATA PRESENTATION AND ANALYSIS}

Around total 170 questionnaires were managed to respondents in Radio 7. The returned questionnaires were carefully coded after which twenty three questionnaires were weeded out as only (147) questionnaires were validated respectively to be consistent for the research and with objective of the study due to the coherent nature of response. Thus, the 147 valid questionnaires which represent $86 \%$ of response rate were considered very significant and the questionnaires were used for the analysis. The data collated are hereby presented in a simple statistical table and the representation of each variables and respondents scores are shown in numbers and percentages as well as their interpretations below. The statistical table was used to present and interpret data gathered through questionnaire; however, since the study used both questionnaire and interview as its research instrument, research questions that were addressed through interview are presented through qualitative approach of presentation and analysis.

Presentation and Analysis of Demographic Data Table 1: Distribution of Respondents as per Gender

\begin{tabular}{|l|c|c|}
\hline Sex & No. of Respondents & Percentage (\%) \\
\hline Male & 80 & 53.3 \\
\hline Female & 67 & 45.57 \\
\hline Total & $\mathbf{1 4 7}$ & $\mathbf{9 8}$ \\
\hline
\end{tabular}

Table 1 Here in the table, 80 of the total respondents are male representing $53.3 \%$ while 67 of the total respondents are female accounting for $45.57 \%$ of the treated population. It could be inferred that respondents' representation according to their gender shows a fair distribution that is very good for research.

Table 2: Distribution of Respondents as per Age

\begin{tabular}{|l|c|c|}
\hline Age & $\begin{array}{c}\text { Number of } \\
\text { Respondents }\end{array}$ & $\begin{array}{c}\text { Percentage } \\
(\%)\end{array}$ \\
\hline $16-25$ & 81 & 54 \\
\hline 26 and Above & 66 & 44 \\
\hline Total & 147 & 98 \\
\hline
\end{tabular}


Table 3: Distribution of Respondents according Occupation

\begin{tabular}{|l|c|c|}
\hline \multicolumn{1}{|c|}{ Occupation } & $\begin{array}{c}\text { Number of } \\
\text { Respondents }\end{array}$ & $\begin{array}{c}\text { Percentage } \\
(\mathbf{\%})\end{array}$ \\
\hline Student staff & 113 & 75.3 \\
\hline $\begin{array}{l}\text { University Staff } \\
\text { (academic) }\end{array}$ & 5 & 12 \\
\hline $\begin{array}{l}\text { University } \\
\text { (non-academic) }\end{array}$ & 11 & 3.3 \\
\hline Others & 147 & 98 \\
\hline Total & & \\
\hline
\end{tabular}

This table contains distribution of respondents' occupation and in fairness to the entire population of the Radio 7, questionnaires were distributed to students of the University resident on campus and off campus (75.3\%), staff of the university (academic and non-academic) $(15.3 \%)$, as well as some campus shuttle drivers and shop owners in the University $(7.3 \%)$, who total up (98\%) to make the audience of the radio station, 90.4 Radio 7.

Table 4: Respondents most preferred Developmental programmes

\begin{tabular}{|l|c|c|}
\hline Programmes & $\begin{array}{c}\text { Number of } \\
\text { Respondents }\end{array}$ & $\begin{array}{c}\text { Percentage } \\
(\boldsymbol{\%})\end{array}$ \\
\hline Aaradhana & 33 & 22 \\
\hline $\begin{array}{l}\text { Nayi Soch Nayi } \\
\text { Udaan }\end{array}$ & 19 & 12.7 \\
\hline Samaj Ki Avaj & 49 & 32.7 \\
\hline Virasat & 13 & 8.7 \\
\hline Hamara Paryavaran & 11 & 7.3 \\
\hline Zara Sochiye & 22 & 14.7 \\
\hline Total & 147 & 98 \\
\hline
\end{tabular}

From the responses gathered from respondents to the questionnaire as presented in the table above, most of the respondents (49) identified with Samaj ki Avaj as their most preferred programme on Radio 7; these responses made up $32.7 \%$ of the total responses. Another programme that Gardners, drivers and some students much listenership in the radio station is the Aaradhana show with $22 \%$ of the respondents identifying it as there most preferred spiritual programme. However, Virasat and Hamara Paryavaran recorded the least responses from the respondents with only $8.7 \%$ and $7.3 \%$ respectively of the respondents choosing it as their most preferred.

Table 6: Responses on whether having campus radio is a good development

\begin{tabular}{|l|c|c|}
\hline Responses & $\begin{array}{c}\text { No. of } \\
\text { Respondents }\end{array}$ & Percentage (\%) \\
\hline YES & 140 & 95.23 \\
\hline NO & 7 & 4.76 \\
\hline Total & 147 & 98 \\
\hline
\end{tabular}

Respondents recorded their answer that there was no doubt among the campus community radio station's community as to whether the establishment of the radio station is a good development or not as all but one of the returned questionnaires (140 of 170) indicated that it is a good development.

Table 7: Purpose for the establishment of the station

\begin{tabular}{|c|c|c|}
\hline Purpose & $\begin{array}{c}\text { No. of } \\
\text { Respondents }\end{array}$ & $\begin{array}{c}\text { Percentage } \\
(\%)\end{array}$ \\
\hline To serve the community & 69 & 46 \\
\hline $\begin{array}{l}\text { To serve as training } \\
\text { centre for students }\end{array}$ & 67 & 44 \\
\hline $\begin{array}{ll}\text { As a tool } & \text { for } \\
\text { development } & \\
\text { communication } & \text { for } \\
\text { community. } & \end{array}$ & 9 & 6 \\
\hline Others & 2 & 1.3 \\
\hline Total & 147 & 98 \\
\hline
\end{tabular}

As deduced from the data gathered and presented in the table above, $46 \%$ of the respondents are of the opinion that the radio station was established to serve the community in all area. Another 67 respondents (representing 44\% of the total respondents) opine that Radio 7 was established to serve as training center for students while only $6 \%$ of the respondents believe the station was established as a tool for development communication for community members.

Table 8: Responses on whether FM Radio 7 allows for community participation

\begin{tabular}{|l|c|c|}
\hline Responses & $\begin{array}{l}\text { No. } \\
\text { Respondents }\end{array}$ & $\begin{array}{l}\text { Percentage } \\
(\boldsymbol{\%})\end{array}$ \\
\hline YES & 134 & 89.3 \\
\hline NO & 13 & 8.7 \\
\hline Total & 147 & 98 \\
\hline
\end{tabular}

Table 9: Responses on ways FM Radio 7 allows for community participation.

\begin{tabular}{|l|c|c|}
\hline Purpose & $\begin{array}{l}\text { No. } \\
\text { Respondents }\end{array}$ & $\begin{array}{l}\text { Percentage } \\
(\boldsymbol{\%})\end{array}$ \\
\hline $\begin{array}{l}\text { Through } \\
\text { programme } \\
\text { development and } \\
\text { broadcasting }\end{array}$ & 33 & 24.6 \\
\hline $\begin{array}{l}\text { Through phone-in } \\
\text { programmes }\end{array}$ & 101 & 75.4 \\
\hline Total & 134 & 100 \\
\hline
\end{tabular}

Table 6 responses from the respondents indicated that FM Radio 7 allows for community participation with statement of 134 out of the total 147 respondents to this assertion. In Table 4.7, of this 134 affirmative response, 101 respondents (representing $75.4 \%$ ) opine that the radio station allows for community participation through phone-in programmes while the other 33 respondents (representing 24.6\%) opine that the station allows for community participation through programme development and broadcasting.

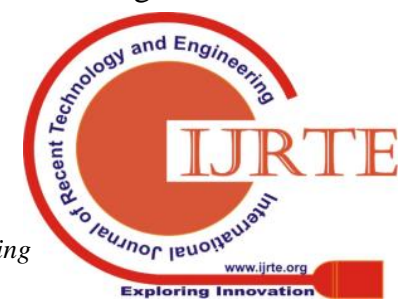


Table 10: Responses on whether listeners have difficulties in tuning into FM Radio 7.

\begin{tabular}{|l|c|c|}
\hline Responses & $\begin{array}{l}\text { No. of } \\
\text { Respondents }\end{array}$ & Percentage (\%) \\
\hline YES & 7 & 4.7 \\
\hline NO & 140 & 93.3 \\
\hline Total & 147 & 98 \\
\hline
\end{tabular}

Respondents were asked whether they have any difficulties in tuning into Radio 7 campus radio station and 140 of the total 147 respondents (representing 93.3\%) said they do not face any difficulties in tuning into the radio station while only $4.7 \%$, mostly residents of the Sanganer and Mansarovar students residential area outside the university premises said they do face some form of difficulties when trying to tune-in to radio station. Going with the response of the majority, it can deduce that the listeners enjoy a clear reception of the radio frequency.

Table 11: Responses on hours of daily listenership

\begin{tabular}{|l|c|c|}
\hline Hours & $\begin{array}{l}\text { No. of } \\
\text { Respondents }\end{array}$ & Percentage (\%) \\
\hline 9.5 hours & 19 & 12.7 \\
\hline $\begin{array}{l}\text { Less than 9.5 } \\
\text { hours }\end{array}$ & 41 & 27.3 \\
\hline $\begin{array}{l}\text { Less than } \\
\text { 5hours }\end{array}$ & 87 & 58 \\
\hline Total & 147 & 98 \\
\hline
\end{tabular}

When the respondents were asked how many hours they listen to the radio station on a daily basis, $58 \%$ said they do listen to the radio station less than 5hours a day. Perhaps, this is not unconnected to the fact that the radio station derives most of its listenership among the students on the campus and broadcast hours run through lecture hours. From the table above, only $12.7 \%$ of the respondents said they tune into the radio station the whole 9.5 hours of broadcast daily; this category being mostly nonacademic staff of the university and the campus shuttle drivers. However, the other $27.3 \%$ respondents said they give Radio 7 more than 5hours but not up to 9.5 hours of their time on a daily basis.

Table 12: Rating of programme quality

\begin{tabular}{|l|c|c|}
\hline Ratings & $\begin{array}{l}\text { No. of } \\
\text { Respondents }\end{array}$ & Percentage (\%) \\
\hline Very Good & 12 & 8 \\
\hline Good & 84 & 56 \\
\hline Fair & 36 & 24 \\
\hline Very poor & 5 & 3 \\
\hline Poor & 10 & 6.7 \\
\hline Total & 147 & 98 \\
\hline
\end{tabular}

Programme rating by listening is also a sine-qua-non for the stations effectiveness. Radio 7 programming enjoys good ratings from its listeners as $56 \%$ score it "Good" mark while another $8 \%$ of the total respondents gave it a Very Good rating. In sum, majority of the respondents $64 \%$ rate the station's programming as Very Good and Good; with only $3 \%$ and $6.7 \%$ of the total respondents rating the programming as Very Poor and Poor respectively.
Table 14: Responses on whether time duration of programme (s) is satisfactory

\begin{tabular}{|l|c|c|}
\hline Responses & $\begin{array}{l}\text { No. } \\
\text { Respondents }\end{array}$ & Percentage (\%) \\
\hline YES & 82 & 54.7 \\
\hline NO & 65 & 43.3 \\
\hline Total & 147 & 98 \\
\hline
\end{tabular}

Although, $43.3 \%$ of the total respondents as gleaned from the above table are of the opinion that the duration of the station's programme is not satisfactory, an above average $54.7 \%$ opine that the duration of programme(s) is satisfactory, thus it can be concluded that most of the radio station's listeners agree with the duration of the station's programme(s).However, a good number of these respondents expressed some level of dissatisfaction with the broadcast timing and duration in totality, pointing out that a question should have been included in the questionnaire to address that.

Table 15: Responses on whether the existence of Radio 7 has added any significant value to listener's life

\begin{tabular}{|l|c|c|}
\hline Responses & No. of Respondents & Percentage (\%) \\
\hline YES & 131 & 87.3 \\
\hline NO & 16 & 10.7 \\
\hline Total & 147 & 98 \\
\hline
\end{tabular}

Beyond doubt, FM Radio 7 has added significant value to life of the community in which it is situated and to the lives of its listeners. This is evident in the above table when respondents were asked whether the radio station has added any significant value to the life of its listeners; 131 of the total 147 respondents (representing 87.3\%) agree that Yes, the existence of Radio 7 has added significant value to the lives of its listeners; with only $10.7 \%$ with a dissenting view.

\section{MAJOR FINDINGS}

1. Findings show that the station was established to serve it host community and also to serve as training centre for students of the university undertaking journalism courses.

2. The establishment of the radio station is seen as a good development for the university community by the members of the community.

3. The station allows for community participation.

4. Source of funding of the radio station is mainly from the management of the university.

5 . The favorable rating of the station by its public is considerably good.

6 . The perception of its public towards its contents and programming quality is relatively good, however, with a need to augment on this.

7. Also, there is the need to augment on the broadcast timing/duration for the sake of students of the university who make up majority of the audience of the radio station.

8 . The researcher discovered some loopholes in the present operational nature of the radio station compared the objectives of its establishment. 


\section{CONCLUSION}

The grassroots is home-based to bulk of the population of nation and the source of wealth and strength, remain largely, marginalized, deprived and voiceless peoples. At a present time mainstream media, including those in the broadcasting sector, have been unable to provide satisfactory coverage and engagement for grassroots governance and development. The problem facing their objective for establishment and effective operation is now what is posing serious challenges to the prospect of bringing broadcasting closer to its immediate community. This research has been able to reveal that the future of campus community radio stations is very bright even though a lot is still needed to make it serve the purpose for which they are established.

As we know it is participatory developmental communication tool that forms the prima facie or tenets of community broadcast entirely must not be neglected but upheld in order to make the establishment of campus radio which is embedded on the premise of community broadcast principle a success. The journey in the direction of the establishment of this station has been good because the station has started fully equipped operation since its commissioning.

\section{REFERENCES}

1. AMARC (1998) what is Community Radio? : A Resource Guide. South Africa: AMARC Africa and Panos Southern Africa

2. Fraser, C., and Estrada, S.R (2010) Community Radio Handbook. Paris: UNESCO

3. Girard, B. 2007 what is Community Media? Retrieved from http://man.comunica.org/archives/101 Accessed: 8 August 2014.

4. McQuail, D. (1987). Theories of Mass Communication.2nd edition. London: Sage

5. Pavarala, V., \& Malik, K. (2007). "Other Voices: The Struggle for Community Radio in India, New Delhi: Sage.

6. Saini, R, (2015) Operational Position Differential of Educational Institution CRS and NGO maintained community radio stations of NCR, Quest International Multidisciplinary Research Journal, July 2015, 2278-4497 Redirected from https://www.researchgate.net/publication/311789757

7. Sahoo, S, (2017) Community Radio Stations: Policy, Participation and Engagement in Odhisha. Communication Today (April-June).

8. Saxena, A, (2011). Radio in New Avatar: AM to PM. New Delhi: Kanishika Publishers.

9. Wimmer, R. D., \& Dominick, J. R., (2003), Mass Media Research: An Introduction.7thedition. Belmont: Wadsworth Publishing Company.

10. World Association of Community Radio Broadcasters (AMARC). 2003. AMARC

11. https://mib.gov.in/document/supreme-court-judgement-airwaves 